在上述范围内原则上反馈系统可得到所有的 各种放电波形, 由于反馈控制的放电波形完 全可以事先设置, 而且非常规范, 因此它成 为研究由于等离子体电流波形改变对磁扩 散、等离子体输运、约束特性和剪切等影响 的有力工具.

\section{参考文献}

[1] 中国科学院物理研究所 104 组、电工研究所 403 组, 物理学报, 1980, 29: 302 .

杨宣宗郑少白蒋地明韩共和王 龙 (中国科学院物理研究所, 北京 100080)

*国家自然科学基金资助项目.

\title{
胶莱盆地中新类型金矿的发现 *
}

作者在华北地台胶莱盆地含炭岩系中发 现具一定工业规模的金矿床. 含炭岩系属下 白严统莱阳群底部层位 $\left(\mathrm{K}_{1} \mathrm{~L}_{1}\right)$, 厚度 $>270 \mathrm{~m}$, 不整合于元古界 - 太古界变质岩上. 该岩系 为黑色泥岩、砾岩、砂岩、泥灰岩及砂质炭酸 盐岩组合, 含有机炭及硫较高, $\mathrm{C}_{\text {标机 }} 0.007 \%$ $9.86 \%$, S $0.036 \%-16.72 \%$; 该岩系近底部 有一赤铁矿层, $\mathrm{TFe} 38.13 \%\left(\mathrm{Fe}_{2} \mathrm{O}_{3} 37.65 \%\right.$, $\mathrm{FeO} 0.50 \%$ ), 属陆相湖泊基底堆积氧化相转 变到还原相的沉积. 据 46 个岩石样品分析 结果, 含炭岩系成矿元素丰度值为: 金 (13$1200) \times 10^{-9}, \bar{X}_{\text {An }} 230 \times 10^{-9}$; 银 $(1000-13110)$ $\times 10^{-9}, \bar{X}_{\mathrm{Ag}} 3937 \times 10^{-9}$; 铅 $(8.90-4238.10)$ $\times 10^{-6}, \overline{\mathrm{X}}_{\mathrm{Pb}} 388.37 \times 10^{-6}$, 锌 $(9.75-17700.00)$ $\times 10^{-6}, \bar{X}_{\mathrm{Zn}} 874.36 \times 10^{-6}$. 明显显示此套地 层富金、银、铅、锌.

已发现的 4 层金矿赋存在此含炭岩系 中, 位置在山东省乳山县、牟平县的崖子、田 家、蓬家乔及谭家。矿体呈层状、似层状、透 镜状顺层产出, 单个金矿层走向延长 $>1000 \mathrm{~m}$, 倾斜方向延深 $>500 \mathrm{~m}$, 厚 $0.8-4.5 \mathrm{~m}$. 矿体 主要赋存在近 E-W 及 NNE 向边界深断裂旁 侧含炭岩系的层间剥离构造空间. 初步研 究, 有 3 种类型的金矿石: (1) 黄铁矿石英矿 石; (2) 含炭泥质赤铁矿石; (3) 金属硫化 物石英矿石. 矿石中自然金 - 自然银系列矿
物的粒度为 $0.01-0.3 \mathrm{~mm}$. 矿石中金 $1.28-$ $70.00 \mathrm{~g} / \mathrm{t}$, 银 $1.63-280.46 \mathrm{~g} / \mathrm{t}$, 铅 $0.056 \%$ $3.822 \%$, 锌 $0.015 \%-9.430 \%$.

作者初步分析, 中生代中期, 胶北隆起遭 受剥蚀, 胶莱盆地接受沉积. 元古代之前地 层中的金、银等经风化剥蚀并被盆地中富含 有机质粘土等吸附初步富集形成较好的矿源 层. 燕山晚期在板块或地体俯冲引张作用下 形成断裂构造导致热液活动, 金 “就地取 材”在富金的含炭岩系所夹的砂岩及砂质碳 酸盐层间构造中富集成矿. 由于元古代之前 胶北隆起上岩石含金的丰度高, 剥蚀时间 长, 古陆边缘盆地的不规则及局限的还原环 境中有机质赋金作用, 导致此套含炭岩系金 丰度值较高, 良好的矿源层形成, 为形成大 型金矿创造了良好的条件. 作者又在相关地 段 (下白严统莱阳群含炭岩系分布的其它地 段) 发现工业金矿。作为层控矿床此新类型 金矿在胶莱盆地及华北地台周边盆地找矿有 难以估量的前景。

张竹如陈世桢 (贵州工学院地质系, 费阳 550003)

*国家“八五”登计划项目. 